24. Qiao X, Tullgren O, Lax I, Sirzen F, Lewensohn R. The role of radiotherapy in treatment of stage I non-small cell lung cancer. Lung Cancer. 2003;41:1-11.

25. McGarry RC, Song G, des Rosiers P, Timmerman R. Observation-only management of early stage, medically inoperable lung cancer: poor outcome. Chest. 2002;121:1155-8

26. Fernandez FG, Crabtree TD, Liu J, Meyers B. Sublobar resection versus definitive radiation in patients with stage IA non small cell lung cancer. J Thoracic Cardiovasc Surg. 2012;94:354-61.

27. Bradley JD, Wahab S, Lockett MA, Perez CA, Purdy JA. Elective nodal failures are uncommon in medically inoperable patients with stage I non-small-cell lung carcinoma treated with limited radiotherapy fields. Int J Radiat Oncol Biol Phys. 2003;56:342-7.

28. Slotman BJ, Antonisse IE, Njo KH. Limited field irradiation in early stage (T1-2N0) non-small cell lung cancer. Radiother Oncol. 1996;41:41-4.

29. Sibley GS, Jamieson TA, Marks LB, Anscher MS, Prosnitz LR. Radiotherapy alone for medically inoperable stage I non-small-cell lung cancer: the Duke experience. Int J Radiat Oncol Biol Phys. 1998;40:149-54.

30. Allen MS, Darling GE, Pechet TT, Mitchell JD, Herndon JE II, Landreneau RJ, et al. Morbidity and mortality of major pulmonary resections in patients with early-stage lung cancer: initial results of the randomized, prospective ACOSOG Z0030 trial. Ann Thorac Surg. 2006;81:1013-20.

31. McKenna RJ Jr. New approaches to the minimally invasive treatment of lung cancer. Cancer J. 2005;11:73-6.

32. Paul S, Altorki NK, Sheng S, Lee PC, Harpole DH, Onaitis MW, et al. Thoracoscopic lobectomy is associated with lower morbidity than open lobectomy: a propensity-matched analysis from the STS database. J Thorac Cardiovasc Surg. 2010;139:366-78.

33. Villamizar NR, Darrabie MD, Burfeind WR, Petersen RP, Onaitis MW, Toloza E, et al. Thoracoscopic lobectomy is associated with lower morbidity compared with thoracotomy. J Thorac Cardiovasc Surg. 2009;138:419-25.

34. Petersen RP, Pham D, Burfeind WR, Hanish SI, Toloza EM, Harpole DH Jr, et al. Thoracoscopic lobectomy facilitates the delivery of chemotherapy after resection for lung cancer. Ann Thorac Surg. 2007;83:1245-50.

35. Flores RM, Park BJ, Dycoco J, Aronova A, Hirth Y, Rizk NP, et al. Lobectomy by video-assisted thoracic surgery (VATS) versus thoracotomy for lung cancer. J Thorac Cardiovasc Surg. 2009;138:11-8.

36. Fernando HC, De Hoyos A, Landreneau RJ, Gilbert S, Goodwing WE, Buenaventura PO, et al. Radiofrequency ablation for the treatment of non-small cell lung cancer in marginal surgical candidates. J Thorac Cardiovasc Surg. 2005;129:639-44

37. Simon CJ, Dupuy DE, DiPetrillo TA, Safran HP, Grieco CA, Ng T, et al. Pulmonary radiofrequency ablation: long-term safety and efficacy in 153 patients Radiology. 2007;243:268-75.

38. de Baere T, Palussiere J, Auperin A, Hakime A, Abdel-Rehim M, Kind M, et al. Midterm local efficacy and survival after radiofrequency ablation of lung tumors with minimum follow-up of 1 year: prospective evaluation. Radiology. 2006;240:587-96.

39. Fakiris AJ, McGarry RC, Yiannoutsos CT, Papiez L, Williams M, Henderson MA, et al. Stereotactic body radiation therapy for early-stage nonsmall-cell lung carcinoma: four-year results of a prospective phase II study. Int J Radiat Oncol Biol Phys. 2009;75:677-82.

40. Henderson M, McGarry R, Yiannoutsos C, Fakiris A, Hoopes D, Williams M, et al. Baseline pulmonary function as a predictor for survival and decline in pulmonary function over time in patients undergoing stereotactic body radiotherapy for the treatment of stage I non-small-cell lung cancer. Int J Radiat Oncol Biol Phys. 2008;72:404-9.

41. Buccheri G, Ferrigno D, Tamburini M. Karnofsky and ECOG performance status scoring in lung cancer: a prospective, longitudinal study of 536 patients from a single institution. Eur J Cancer. 1996;32A:1135-41.

42. Berrisford R, Brunelli A, Rocco G, Treasure T, Utley M. The European Thoracic Surgery database project: modelling the risk of in-hospital death following lung resection. Eur J Cardiothorac Surg. 2005;28:306-11.

43. Kozower BD, Sheng S, O’Brien SM, Liptay MJ, Lau CL, Jones DR, et al. STS database risk models: predictors of mortality and major morbidity for lung cancer resection. Ann Thorac Surg. 2010;90:875-83.

44. Wright CD, Gaissert HA, Grab JD, O'Brien SM, Peterson ED, Allen MS. Predictors of prolonged length of stay after lobectomy for lung cancer: a Society of Thoracic Surgeons General Thoracic Surgery database risk-adjustment model. Ann Thorac Surg. 2008;85:1857-65.

45. Palma D, Visser O, Lagerwaard FJ, Belderbos J, Slotman BJ, Senan S. Impact of introducing stereotactic lung radiotherapy for elderly patients with stage I nonsmall-cell lung cancer: a population-based time-trend analysis. J Clin Oncol. 2010;28:5153-9.

46. Robinson CG, El Naqa I, Crabtree T, Meyers B, Puri V, Zoole J, et al. Outcomes after stereotactic body radiation therapy (SBRT) or anatomic surgical resection (ASR) for clinical stage I non-small cell lung cancer. Int J Radiat Oncol Biol Phys. 2010;78:S15.

\title{
COMMENTARY
}

\section{The best that surgery has to offer}

\author{
Thomas A. D'Amico, MD
}

The treatment of patients with stage I lung cancer continues to be examined through decades of controversy:

From the Division of Thoracic Surgery, Department of Surgery, Duke University Medical Center, Durham, NC.

Disclosures: The author has nothing to disclose with regard to commercial support. Received for publication Nov 9, 2012; accepted for publication Dec 5, 2012; available ahead of print Jan 10, 2013.

Address for reprints: Thomas A. D'Amico, MD, Section of General Thoracic Surgery, Duke University Medical Center Box 3496, Duke South, White Zone, Room 3589,

Durham, NC 27710 (E-mail: damic001@mc.duke.edu).

J Thorac Cardiovasc Surg 2013;145:699-701

$0022-5223 / \$ 36.00$

Copyright (C) 2013 by The American Association for Thoracic Surgery

http://dx.doi.org/10.1016/j.jtcvs.2012.12.020 lobectomy versus sublobar resection, minimally invasive strategies versus open approaches, and most recently the use of nonsurgical interventions versus resection. Each of these debates pivots on the competing principles of optimizing oncologic efficacy while minimizing invasiveness and complications. Although the Lung Cancer Study Group established lobectomy as the standard of care for clinical stage I lung cancer, ${ }^{1}$ those findings are being challenged by trials demonstrating equivalent results with segmentectomy in selected patients ${ }^{2}$ and currently being tested again in a prospective, randomized trial (Cancer and Leukemia Group B 140503). ${ }^{3}$ More clearly established is the 
superiority of thoracoscopic lobectomy compared with open approaches. ${ }^{4,5}$

The role of surgery in the management of patients with clinical stage I lung cancer is now being challenged by the emergence of 2 nonsurgical interventions: radiofrequency ablation (RFA) and stereotactic body radiation therapy (SBRT). RFA has been demonstrated to be safe and effective in selected patients with lung cancer in several studies and is under evaluation now in a recently completed multiinstitutional prospective phase II study: American College of Surgeons Oncology Group [ACOSOG] Z4033. ${ }^{6}$ In addition, SBRT has been used with success in the management of clinical stage I lung cancer, most notably in a prospective phase II study (Radiation Therapy Oncology Group 0236), ${ }^{7}$ and it is currently being compared with sublobar resection in a prospective, randomized trial: ACOSOG Z4099. ${ }^{8}$

As all practitioners involved in the multidisciplinary management of lung cancer await the results of this study, a recent comparative analysis of completed clinical trials of RFA, SBRT, and sublobar resection may improve our understanding of these 3 competing techniques. ${ }^{9}$ The stated purposes of this analysis were to compare selection criteria and to assess the short-term outcomes of the 3 studies. The power of this analysis is limited by several factors, including the size of the RFA study (ACOSOG Z4033; $\mathrm{n}=51$ ) $^{6}$ and the size of the SBRT study (Radiation Therapy Oncology Group 0236; $\mathrm{n}=55$ ). ${ }^{7}$ The complications that may have arisen from the biopsy procedures in the nonsurgical trials was not assessed. Another important limiting factor is the allowance of wedge resections (more than two thirds of patients) and thoracotomy (more than one third of patients) in the sublobar resection trial (ACOSOG Z4032) ${ }^{10}$ strategies that proved to be inferior to anatomic and thoracoscopic approaches in this patient population. $^{2,4,5}$ In addition, comparisons between nonsurgical techniques and resection are limited by the use of clinical, as opposed to pathologic, staging. It is also difficult to assess patient selection in the nonsurgical trials-why patients were turned down for surgery. Pulmonary function tests are relatively objective, but measuring frailty and other comorbid conditions is more complex. Finally, although the assessment of short-term outcomes is important, the absence of long-term oncologic outcomes does limit the conclusions of any comparative analysis.

Although there were some statistically significant differences among the 3 trials in pretreatment clinical parameters (age and pulmonary function), there are 4 important results that are elucidated in this analysis. ${ }^{9}$ First, $29.3 \%$ of patients in the sublobar resection trial were upstaged (clinical stage vs pathologic stage) after surgery. Although there were some differences in the baseline characteristics of the 3 trials, one must assume that the assignment of clinical stage underestimates the pathologic stage in $25 \%$ to $30 \%$ of patients treated by RFA and SBRT. Although the ongoing prospective randomized trial comparing SBRT and sublobar resection will more definitively address this question when the incidences of local and regional recurrences between the 2 techniques can be compared, the issue of clinical understaging and assignment of interventional therapy remains of concern.

Second, the propensity-matched analysis demonstrates no difference in the development of significant adverse events $(3+)$ after SBRT and sublobar resection. Although the complication profile after resection of lung is well understood, ${ }^{4,5}$ it may be erroneously assumed that SBRTdescribed as noninvasive-is associated with a lower procedural risk. Although the number of post-therapy deaths was higher in the sublobar resection group, the rate of $3+$ adverse events was not significantly different. Accurate risk assessment will certainly be important in the selection of therapy for patients with marginal pulmonary function or other comorbid conditions.

Also of note, the post-treatment decline in pulmonary function was not significantly different in patients treated with SBRT or sublobar resection. Although it may be difficult to draw conclusions in an analysis of patients treated with 2 different modalities in 2 separate clinical trials, the possible assumption by clinicians evaluating patients with clinical stage I lung cancer and marginal pulmonary function that SBRT is associated with higher preservation of pulmonary function may be incorrect. Again, this question will be better addressed in the ongoing prospective trial.

Finally, it must also be pointed out that approximately $13 \%$ of patients in the sublobar resection trial had no documented lymph node staging. ${ }^{9}$ I believe it is safe to assume that a significant fraction of patients in this trial also did not have the minimum of 3 mediastinal lymph nodes assessed, as is recommended by current clinical guidelines. ${ }^{11}$ That, in conjunction with the fact that approximately two thirds of the patients underwent wedge resection as opposed to segmentectomy and approximately one third of patients underwent resection via thoracotomy as opposed to thoracoscopy, ${ }^{6}$ describes a therapeutic surgical strategy that is suboptimal and may prove to be inferior to SBRT in the randomized trial. This ongoing trial may define how patients with clinical stage IA cancers will be treated in the future, a population that is likely to grow as lung cancer screening becomes more prevalent. These patients may not be receiving the ideal therapy in the future if surgeons do not recognize and practice the best that surgery has to offer in optimizing oncologic efficacy while minimizing invasiveness and complications.

\section{References}

1. Ginsberg RJ, Rubinstein LV. Randomized trial of lobectomy versus limited resection for T1 N0 non-small cell lung cancer. Lung Cancer Study Group. Ann Thorac Surg. 1995;60:615-22.

2. Okada M, Koike T, Higashiyama M, et al. Radical sublobar resection for smallsized non-small cell lung cancer: a multicenter study. J Thorac Cardiovasc Surg. 2006;132:769-75.

3. Phase III randomized study of lobectomy versus sublobar resection in patients with small peripheral stage IA non-small cell lung cancer. Available at: 
http://www.cancer.gov/clinicaltrials/search/view? cdrid $=555324 \&$ version $=$ HealthProfessional. Accessed November 4, 2012.

4. Villamizar NR, Darrabie MD, Burfeind WR, Petersen RP, Onaitis MW, Toloza EM, et al. Thoracoscopic lobectomy is associated with lower morbidity compared to thoracotomy. J Thorac Cardiovasc Surg. 2009;138:419-25.

5. Paul S, Altorki NK, Sheng S, et al. Thoracoscopic lobectomy is associated with lower morbidity than open lobectomy: a propensity-matched analysis from the STS Database. J Thorac Cardiovasc Surg. 2010;139:366-7.

6. Radiofrequency ablation in treating patients with stage I non-small cell lung cancer. Available at: http://clinicaltrials.gov/ct2/show/NCT00109876. Accessed November 4, 2012

7. Timmerman R, Paulus R, Galvin J, et al. Stereotactic body radiation therapy for inoperable early stage lung cancer. JAMA. 2010;303:1070-6.

8. Phase III randomized study of sublobar resection with or without brachytherapy versus stereotactic body radiotherapy in high-risk patients with stage I non-small cell lung cancer. Available at: http://www.cancer.gov/clinicaltrials/search/view? cdrid $=698986 \&$ version $=$ HealthProfessional. Accessed November 4, 2012.

9. Crabtree T, Puri V, Timmerman R, et al. Treatment of stage I lung cancer in high risk and inoperable patients: comparison of prospective clinical trials utilizing stereotactic body radiation therapy (RTOG 0236), sublobar resection (ACOSOG Z4032), and radiofrequency ablation (ACOSOG Z4033). J Thorac Cardiovasc Surg. November 19, 2012 [Epub ahead of print].

10. Fernando HC, Landreneau RJ, Mandrekar SJ, et al. Thirty- and ninety-day outcomes after sublobar resection with and without brachytherapy for non-smal cell lung cancer: results from a multicenter phase III study. J Thorac Cardiovasc Surg. 2011;142:1143-51.

11. Ettinger DS, Akerly W, Borghael H, et al. National Comprehensive Cancer Network (NCCN). Non-small cell lung cancer clinical practice guidelines in oncology. J Natl Compr Canc Netw. 2012;10:1236-71. 